\title{
Adapting Practices of Science Journalism to Foster Science Literacy
}

JOSEPH L. POLMAN, ${ }^{1}$ ALAN NEWMAN, ${ }^{2}$ ELLEN WENDY SAUL, ${ }^{2}$ CATHY FARRAR ${ }^{3}$

${ }^{1}$ School of Education, University of Colorado Boulder, Boulder, CO 80309, USA;

${ }^{2}$ College of Education, University of Missouri-St. Louis, St. Louis, MO 63121, USA; and

${ }^{3}$ Rockwood (Missouri) School District, St. Louis, MO 63025, USA

This is the peer reviewed version of the following article:

Polman, J. L., Newman, A., Saul, E. W. \& Farrar, C. (2014). Adapting practices of science journalism to foster science literacy. Science Education, 98(5), 766-791.

which has been published in final form at https://doi.org/10.1002/sce.21114. This article may be used for non-commercial purposes in accordance with Wiley Terms and Conditions for Self-Archiving." 


\title{
Adapting Practices of Science Journalism to Foster Science Literacy
}

\author{
JOSEPH L. POLMAN,${ }^{1}$ ALAN NEWMAN, ${ }^{2}$ ELLEN WENDY SAUL,${ }^{2}$ CATHY FARRAR ${ }^{3}$ \\ ${ }^{1}$ School of Education, University of Colorado Boulder, Boulder, CO 80309, USA; \\ ${ }^{2}$ College of Education, University of Missouri-St. Louis, St. Louis, MO 63121, USA; and \\ ${ }^{3}$ Rockwood (Missouri) School District, St. Louis, MO 63025, USA
}

\begin{abstract}
In this paper, the authors describe how the practices of expert science journalists enable them to act as "competent outsiders" to science. We assert that selected science journalism practices can be used to design reformbased science instruction; these practices not only foster science literacy that is useful in daily life, but also complement practices of scientists that already have been incorporated into science education. We describe and illustrate science journalism practices for educational activities that can be adapted and used. We argue that such experiences enable students to better use science information for personal decision-making and help them contribute meaningfully to public discourse long after high school graduation. Finally, we describe the design of a learning environment that facilitates research and development based on this model.
\end{abstract}

KEYWORDS: science literacy, curriculum, learning, journalism, practices

\section{INTRODUCTION}

Since the cognitive revolution of the 1950s (Miller, 2003), educators have commonly looked to experts for practices that can be adapted to education in the disciplines (e.g., Bransford, Brown, and Cocking, 2000; Schwab \& Brandwein, 1962). Expert historians are used to model and define ways thinking and doing in history class (e.g., Wineburg, 
2001). Expert mathematicians' thinking and actions are routinely modeled in mathematics instruction (e.g., Lampert, 1986). Roberts (2011) has observed that the practices of expert scientists have served as the model to which much of science education attends. Since knowing science has typically been seen as thinking and acting like expert scientists, Roberts argues that curriculum and practice in science education has been dominated by efforts to educate children to think like and carry out the practices of science the way that insiders in the profession do. Although there have been influential critiques of this approach (e.g., Aikenhead, 2006). Science education reform efforts have focused primarily on what it means to know and work as practicing experts know and do science. In the last twenty years apprenticeship has been seen as key to curriculum reform (Polman, et al., 2010).

Knowing science has typically been seen as having conceptions consonant with those of expert scientists (e.g., diSessa, 2006); "talking science" like a scientist (Lemke, 1990); using reasoning about models (e.g., Lehrer \& Schauble, 2006), and spatial representations like scientists (e.g., Schwartz \& Heiser, 2006); and knowing how to carry out the authentic inquiry practices of scientists (e.g., Edelson \& Reiser, 2006; Krajcik, et al., 1998; O'Neill \& Polman, 2004). Coming to know science has frequently been encouraged by creating communities of practice carrying out science inquiry (e.g., Pea, 1993; Rosebery, Warren, \& Conant, 1992; Ruopp, Gal, Drayton, \& Pfister, 1993). Learning environments based on a community of practice model have taken inspiration from the research on traditional apprenticeship learning (e.g., Lave $\&$ Wenger, 1991), and the related concept of cognitive apprenticeships for learning in schools (Brown, Collins, \& Duguid, 1989; Collins, Brown, \& Newman, 1989).

These views of science knowing and learning have had a profoundly positive impact on education in the United States in the last two decades, through direct reform and by being taken up and elaborated on in influential reports that have resulted in more research-based curriculum and pedagogy gaining exposure and influencing policy and practice (e.g., Bransford, Brown, \& Cocking, 2000; Duschl, Schweingruber, \& Shouse, 2007; Michaels, Shouse, \& Schweingruber, 2008), the first generation standards for science education (National Research Council, 1996, 2000), and the new framework for the next generation science standards (National Research Council, 2012b). The tendency to base science learning goals on analysis of the expertise of practicing scientists is understandable, but it has important limitations relative to how science is used in everyday life (e.g., Feinstein, 2011; Feinstein, Allen \& Jenkins, 2013). These views have also had an impact on international organizations such as the Organisation for Economic Cooperation and Development, and their PISA assessments (e.g., OECD, 2009), though that effort has tended to include more direct consideration of the place of science in everyday life.

How do high school science experiences relate to the life of young people outside of the classroom now, and 15 years after they graduate? For the students involved in the reform-based instruction we describe in this paper, the connections to personal decisions and engagement in public discourse are apparent. Young people weigh the health risks in getting a tattoo, playing football after a concussion, or going to a tanning salon. On a daily basis, they decide whether to drink soda and the latest boutique sports drinks, eat fast food, or buy a bracelet that claims to boost strength. They worry about their dad who has diabetes and their grandmother fighting breast cancer. In the future, they and their family members will decide whether to try alternative medicines, new drugs, or undergo an invasive procedure for health conditions they face. Their families sometimes face environmental hazards such as mold in their homes, rats in the alley or toxic waste sites in their communities. They make purchasing decisions regarding new technologies. Long after they graduate, they will continue to make personal decisions like these, 
which can be informed by science. They sometimes participate in public discourse and debates that science can inform, as well. School communities debate whether or not to install artificial turf in their stadiums, or how much money to invest in green construction and recycling practices. Public policy must deal with issues like building new oil pipelines and increased monitoring of electronic communications, and some youth get involved in campaigns related to such issues. And then there are the developments that we can't even predict 15 years into the future, just as 15 years ago it was difficult to anticipate embryonic stem cells and 3-D printers. Regardless of their current involvement in public debates, as educators we want our young people of today to become engaged citizens who can capably make use of the latest science to inform public policy.

We assert that the extent to which people can address challenges such as those listed above indicates the extent of their "science literacy" ${ }^{1}$ in its most fundamental sense. Highly educated individuals, even with degrees in science fields, often do not have experience researching and making sense of issues like diet recommendations advocated in the popular press or whether "fracking" for oil is safe. Business or liberal arts majors often take courses in areas such as earth science, but those classes may not prepare them to make sense of the latest in the climate change debates raging on the Internet, because the science can change quickly and courses typically focus on the basic science rather than its contemporary applications.

Unfortunately, we know that many citizens have long been hesitant to use science for their public and personal decision-making, and some may be less inclined to do so than they once were. An analysis by Gauchat (2012) shows that class, ethnicity, church attendance, geographic region, and gender have had an impact on trust in science for decades, but there is also an increasing correlation between political affiliation with the conservative movement in the United States and a distrust and disregard for science. Alarmingly, college educated conservatives are more likely to be climate change deniers than those with less education (Pew Research Center for the People \& the Press, 2009). We believe that all segments of the public should make maximum use of the public and private investment in science to inform our choices, regardless of political or any other affiliation or identification. This does not imply uncritical use of science research; on the contrary, we want all segments of the population to be prepared to be critical, wellinformed consumers of science information, and participants in public discourse about topics informed by science.

The explosion of scientific and technical knowledge presents an additional challenge for all citizens (Aikenhead, Orpwood, \& Fensham, 2011; Seethaler, 2009). Although it is immensely helpful to have a basic understanding of important scientific concepts, and an understanding of how science is practiced, such an understanding is not enough. In order to possess science literacy that is useful (Feinstein, 2011; Feinstein, Allen, \& Jenkins, 2013), one must have means to find, evaluate, and make sense of new scientific and technical information that cannot be predicted or completely and comprehensively taught in high school. Moreover, science evolves too quickly for it to be anchored in a high school textbook; who would treat their child's asthma with 15-year-old information? What competent citizens need to do is see what science is relevant

${ }^{1}$ As Roberts (2007) has observed, the terms "scientific literacy" and "science literacy" have long been used interchangeably, with sometimes contested and sometimes no difference in meaning. In this paper we will use the terms "science literacy" and "scientifically literate", and follow Roberts in using "SL" as an abbreviation. Nonetheless, our definition of these terms fits with that of some who use other terms for SL. See below. 
to their lives and decisions. They need to find and make use of credible sources of science information that connect to their concerns, while taking account of the expertise and biases of those sources. They need to understand how new science fits within the context of the fields of inquiry from which it originates, and also contextualize that science within broader societal concerns, such as economics and ethics. And they need to make sense of enough of the science concepts and ideas related to their concerns, even though they will never know as much as an expert who has devoted countless hours to an area of study. The most competent citizens will not be afraid of science, nor see it as a mysterious realm of practice and information only discussed by the highly credentialed (Postman, 1992). The citizens most well-equipped will see science as across life - not just in science classrooms.

In many ways, our goals for the effect science education should have 15 years after graduation mirror the 21st Century Workforce Skills advocated by the United States National Academies (NRC, 2012a). Those skills include adaptability to deal with new and rapidly changing work conditions, complex communication and social skills in order to digest information, nonroutine problem solving, self-management and self-development, and understanding how an entire system works by looking at the whole picture.

In this paper, we situate ourselves within the debates on science literacy, then briefly review the challenge of identifying the most useful "expert models" for scientifically literate adults. We then describe what is promising about science journalists as an expert model, and an associated set of criteria for science literacy. We then describe the theory behind and design of a learning environment where youth citizen science journalism is intended as a context for developing scientifically literate publics. We will illustrate the power of this model for fostering competent use of science for personal and public life, using examples from an educational intervention called SciJourn.

\section{THE NEED FOR "COMPETENT OUTSIDERS"}

There are a number of approaches in science education to fostering science literacy, each based on a combination of a vision for what a scientifically literate student should know and be able to do, and to some degree on a model of a scientifically literate individual. As has been extensively discussed in the literature, the terms "scientific literacy" and "science literacy" (SL) have a long and contested history (e.g., American Association for the Advancement of Science [AAAS], 1989; DeBoer, 2000; dos Santos, 2008; Eisenhart , Finkel \& Marion, 1996; Hurd, 1958, 1998; Linder et al., 2011; Norris \& Phillips, 2003; Roth \& Barton, 2004; Roth \& Lee, 2004; Shamos, 1995; Turner, 2008).

Douglas Roberts' $(2007,2011)$ distinction between two competing visions of SL helps to illuminate the consequences of differing approaches. He asserted that "Vision I", or literacy as thorough knowledgeability within science, has traditionally dominated school curricula and assessment in the US and internationally. The expert models to whom Vision I refers are practicing scientists, as they provide insights for researchers, curriculum designers, and teachers for how science is conceptualized and practiced from the inside. Within Vision I, there is a good deal of healthy debate on how best to foster understanding among learners of science concepts, and facility at carrying out science inquiry and practices. But having all students become generalized "little scientists" (e.g., O'Neill \& Polman, 2004) is impossible; it is highly unlikely that all students will leave high school with detailed conceptual understanding and highly refined inquiry skills in all the subdisciplines of science that affect private and public life. And as noted above, once they leave school, former students can't actually carry out first-hand inquiry into 
each of the science-technology tinged issues that they face. For instance, in order to investigate how best to deal with a daughter's allergies, a mother is not likely to have the time or facilities to set up her own controlled trials or do her own analyses of the allergen data.

In contrast to Vision I, Roberts $(2007,2011)$ distinguished "Vision II" SL as thorough knowledgeability about science-related situations that students are likely to encounter in everyday life, such as the personal and public decisions described in the beginning of this article. This does not mean that Vision I understandings are irrelevant. Along with most of the contributors to a recent volume on SL (Linder et al., 2011), we seek to articulate and explore the possibilities of prioritizing Vision II in order to create a need to know concepts and practices that are traditionally a part of Vision I initiatives. Another way of saying our focus is on usefulness in everyday life is to say we are concerned with SL-in-action (Aikenhead et al., 2011), focusing on the actual uses of science in daily life outside the pipeline to science careers (Feinstein, et al., 2013). Regardless of their career choice, citizens will face several kinds of situations involving science and technology information: personal choices such as treatments for health conditions and adoption of new technologies, public debates such as those around policy related to climate change, and aesthetic/cultural appreciation (e.g., Layton, Jenkins, Macgill, \& Davie, 1993). As Feinstein (2011) pointed out, such SL involves acting as competent outsiders to science. By his definition, competent outsiders are "people who have learned to recognize the moments when science has some bearing on their needs and interests and to interact with sources of scientific expertise in ways that help them achieve their own goals" (p. 180).

\section{THE EXPERT MODEL OF SCIENCE JOURNALISTS}

As stated in the introduction, the expert model for educating Vision I SL is crystal clear: the practicing scientist. For educational researchers, curriculum designers, and teachers who are concerned with educating Vision II competent outsiders to science, the expert model for useful SL is less clear. As Feinstein (2011) notes, some effective projects look to community groups such as those doing environmental activism, and in turn design curricula around "socioscientific issues" and activism at the local community level. Two examples exploring this model are Eisenhart et al.'s (1996) and Roth \& Lee's (2004) ethnographic research on school initiatives partnered tightly with the work going on in particular ongoing community organizations. In their exploration of curricula built on a student inquiry and activism model related to environmental projects, Bouillon \& Gomez (2001) demonstrated the "contextual scaffolds" such initiatives take advantage of, while Calabrese Barton and colleagues (Calabrese Barton, Tan, \& Rivet, 2008; Calabrese Barton \& Tan, 2010) have shown the ways that opportunities for agency help drive learning as well as positive shifts in science identity (i.e., learners identifying more with possible science careers, and/or seeing science as connected to who they are, rather than disconnected). Other educators have designed curricula, activities, and assessments that challenge young people to conduct inquiry into and then take positions on controversial socioscientific issues, culminating for instance in debates (e.g., Linn, Clark, \& Slotta, 2003; Zeidler \& Sadler, 2011). In addition, a growing number of "citizen science" initiatives involve young people and adults in data collection, and ideally analysis, related to natural phenomena of interest in the world around them, such as monarch butterfly migration, bird watching, comet hunting, native plant and habitat restoration, and whale watching. Such initiatives take place within (e.g., Feldman, Konold, and Coulter, 2000) and beyond schools (e.g., Brossard, Lewenstein, \& Bonney, 2005).

In this paper, we develop an alternate expert model on how to be a "competent outsider": science journalists. In the SciJourn project, our research group has explored how the cultural 
practices of good science journalists provide lessons for education (Polman, Newman, Farrar \& Saul, 2012; Saul, Kohnen, Newman \& Pearce, 2012). In SciJourn, youth in middle and high schools as well as out-of-school programs learn science by doing science news reporting, with the opportunity to submit their science news stories to an authentic publication with a rigorous editorial process.

\section{Overview of Expert Science Journalism}

In addition to a review of professional journalism literature, our team utilized content analysis of (1) a focus group interview of practicing science journalists and journalism educators and (2) twenty-one readaloud-thinkaloud interviews of science journalists, scientists and science educators reading two science news articles, one in their field of expertise and one not, in order to develop a characterization of ideal science reading practices. The following is an overview of the patterns of thought and action we have identified, contextualized in the literature on ideal print science journalism (e.g., Blum, Knudson, \& Henig's (2006) guidelines of the National Association of Science Writers (NASW), and Kovach \& Rosenstiel (2007)), as well as selected mass communication literature. We focused on print science journalism because our work to date has primarily involved young people reading and writing text-based news stories (though we have since branched out to other media forms, see Lamb, Polman, Newman, \& Graville Smith, 2014). In our experience, podcasts and video added technical challenges that took time away from the primary goal of improved SL. Traditionally, journalists aim to "[disseminate] accurate information regarding science and technology" (NASW, n.d.), particularly what is new and controversial. Though most journalists do not believe it is their responsibility to "educate" the public per sé (Gregory \& Miller, 1998), many science communication experts concur that the ideal role of the reporter is to tackle a question of current interest to the readership; investigate it by talking to multiple, credible sources; digest the information, including both sides of any controversies and the relevant technical information; and summarize it without bias and in a way that the general public can understand (e.g., Nelkin, 1995; Shute, 2006).

Print journalists structure their stories to forefront what's new or newsworthy in the first few paragraphs, called the "nut graph" (Shie, 2012). The nut graph not only hits the classic who, what, where, when and how, but provides a clear, succinct and accurate "take home" message. If all the reader needs is basic information, there is no need to read the full article, and no need to sort through five paragraphs of introduction to get to the heart of the issue. In fact, journalists write stories as if most readers will not read the full article, and rarely provide a conclusion.

A good journalist also attributes anything new or information that is not considered common knowledge (Evans, Krippendorf, Yoon, Posluszny \& Thomas, 1990; Shute, 2006; Yam, 2006). The attribution explains why the person or group is being quoted and their status - "according to the environmental group Greenpeace"; "says Phillipa Green, an evolutionary biologist at Tulane University and lead author;" "explains physicist Wen Hiu, who was not associated with the new research." This helps the reader to know who said what and to judge the source's credibility. It also leaves a historical trail of where ideas and inventions originated.

Ideally, the news is presented in context - how many affected, how much will it cost or save, whether and how it is better, nascent idea or well accepted by scientists, and so on (Evans, Krippendorf, Yoon, Posluszny \& Thomas, 1990; Pellechia, 1997; Siegfried, 2006; Yam, 2006). Details of the discovery follow, with comments on the news from experts who are not part of the research or have a financial tie to its success. Thus, by our criteria a good article relies on multiple, credible sources. It doesn't mean that the story arrives at the "truth," but it is more 
honest than a press release or an advertisement because those genres tend to portray only one perspective. In the case of research press releases, only the perspective of the researcher or researchers who originated the study are presented; in the case of advertisements, only the perspective of the manufacturer and perhaps experts whom they "cherry-pick" because they support their own sales or marketing goals are reported. Bloggers can pose the same problem and it is sometimes difficult to establish their credibility.

The expert science journalist may not always be someone with a degree in science, but with time he or she has learned to navigate science communities, understand how science experts work, and can make sense of and translate technical language. Science journalists also have access to credible experts who can provide the broader view on any new discovery, therapy or technology. The science journalist may even be able to comprehend the primary literature of peer-reviewed articles (e.g., Blum, Knudson, \& Henig, 2006; Gregory \& Miller, 1998; Siegfried, 2006).

Journalists and their editors also traditionally play another important role - they are the gatekeepers, and they serve as proxies for their readers by filtering for the most credible and meaningful information (Gregory \& Miller, 1998). They protect their credibility by striving to keep unsubstantiated rumors, bad science and false technologies out of the newspaper or at least in perspective. As Blum, Knudson, and Henig state, "balance in science writing requires authorial guidance, it requires context, and knowing when certain points of view simply need to be ignored" (p. ix, 2006). In other words, good science reporters and editors recognize when something is consensus science, and even if there is "another side," the consensus needs to be recognized as such, and more marginal positions should be downplayed (Kovach and Rosenstiel, 2007). Similarly, embryonic science is often newsworthy, but good journalists aim to contextualize the tentativeness of new findings relative to more established lines of inquiry.

Although journalism professionals such as those we interviewed, and documents such as the NASW's "official" field guide for science writers (Blum, Knudson \& Henig, 2006) tout the practices cited above as worthy, science communication studies have consistently shown that these practices are aspirational and not consistently realized in published journalism. For instance, Evans, Krippendorf, Yoon, Posluszny \& Thomas (1990) found that most news stories published in the New York Times and Philadelphia Inquirer include the names and affiliations of researchers, but in their analyses only $35 \%$ of stories put the science news in the context of prior research, and 16\% note limitations. Pellechia (1997) performed an analysis of stories over a period of three decades of the New York Times, the Washington Post, and the Chicago Tribune. Most stories identified the source of research (around 70\%), institutional affiliation of researcher (around 90\%), and had a mean number of 4 comments from the researcher who conducted the study. But they do not contextualize the study very well (40-50\% contextualize in prior studies, and cite limitations), or include much information from sources other than the main subject of the story (the mean number of comments from such sources across stories was well below one, but increasing over time).

\section{Science Journalism Today}

Today's high school students overwhelmingly get their news from the Internet (Flanagin and Metzger, 2010). According to the Pew Internet and American Life Project, the Internet had equaled television as the most popular source for science news among people younger than 30 as of 2006. Among all adults in the U.S., one quarter (40 million) say they get most of their science news and information from the Internet, and by $200687 \%$ of Internet users had ane time gone 
online to get some piece of information about science (Horrigan, 2006). Not surprisingly, science journalism has also migrated to the Web (Brainard, 2009). A 2009 survey of 493 active science journalists found that while many still had their stories in print, the number of writers who had their stories also on the Web rose from 50\% five years earlier to $75 \%$. More journalists were blogging, as well (Brumfiel, 2009).

However, the Internet as a whole has no gatekeeper function - the credible expert is side by side with the charlatan or the blatant commercial. Webmasters can manipulate their sites to look more credible (Coiro, 2003) or purchase a choice position on keyword returns on search engines. Commercial interests have developed sophisticated means to support and publicize biomedical and public health research so that only results that support their bottom line dominate the media and influences policy (McGarity \& Wagner, 2008; Michaels, 2008). Simple rules often taught in schools to help students navigate to more credible sources (e.g., do not use "dot com" sources), fail when considering the fact that WebMD.com, for instance, is a source of credible medical information. Likewise, "dot orgs" can be commercial associations that promote certain products or ideas. Worse yet, there were 22 top-level domain names, as they are known, along with country names, in 2011 before the International Corporation for Assigned Names and Numbers opened the door to hundreds more on the Internet. What to make of "dot ca" (Canada) or "dot int" (international research institute)?

On a subtler level, many online science stories are little more than recycled press releases, which may well be credible, but are usually one-sided (Russell, 2008). Moreover, 35 top US research universities launched Futurity (http://www.futurity.org/) in 2009 because of what they felt was a lack of science coverage in mainstream media. The consortium now includes universities from Canada and Great Britain. It is a high profile group, but their news is all contained within press releases. ScienceDaily (http://www.sciencedaily.com) is essentially all press releases as well. Finally, all too often other science news sources with limited science news reporting budgets publish minimally edited press releases, resulting in what Nick Davies (2008) has termed "churnalism." An outcome of this situation is that preliminary science or medical treatments may be hyped as more established than the broader research community would deem to be the case, which has long been a problem that concerns scientists about journalism (Gregory \& Miller, 1998; Nelkin, 1995).

\section{Science Journalism in Educational Contexts}

Science journalism has received relatively little attention in science education, and most of the focus has been on facilitating how students read science news. Norris \& Phillips (1994) found that even strong students did not understand the scientific context or qualifications of information in science news stories. Korpan, Bisanz, Bisanz, \& Henderson (1997) use science news reading to work towards building an understanding of the nature of science. Korpan et al. have involved students in reading reports of science studies, critiquing the science methodology and conclusions, and if there is not enough information, generating ideas on what further information would be needed to make sound scientific conclusions. This is a laudable effort at using authentic contemporary reading materials in science classes, but the focus in their efforts has been on using analyses of science news to drive Vision I SL. Jarman \& McClune (Jarman \& McClune, 2007; McClune \& Jarman, 2012) have also elaborated how science newspaper reading can be an engaging and vibrant contributor to elementary grade students' understanding of science concepts and practices (Vision I SL) as well as preparation for encountering science in everyday life (Vision II SL). 
In contrast to these few researchers who have focused on reading science news, David Williamson Shaffer and David Hatfield have sought to involve young people in the writing of science news (Hatfield, 2011; Hatfield \& Shaffer, 2006; Shaffer 2006). In their "epistemic game" called "Science.net", these researchers scaffold middle school students in the writing of investigative news stories in an online environment during intensive summer camps. The scaffolding and activities in which these young people are involved are based on an ethnography conducted by the research team of a practicum course ("Journalism 828") at the university level and a study of a professional news organizations (Shaffer, 2005). These researchers stress young people taking on the identities, values, and key epistemic practices identified in the ethnography of college students learning to become investigative journalists: writing as a watchdog, writing for story, and writing to formula. Shaffer (2005) puts forth three participant structures (Herrenkohl \& Guerra, 1998; Philips, 1972) that facilitate the development of these epistemic practices in Science.net:

War stories emphasized writing as a watchdog: the importance of drawing attention to inequities, monitoring people and institutions in positions of power, and offering a voice to those without power. News meetings emphasized writing for story: the importance of telling stories about particular people encountering problems or conflict, those people's individual thoughts and actions, and the specific events that happened and the unique details surrounding them. Copyediting emphasized writing to formula: the importance of using specific methods of journalistic writing, rules of journalistic style, and traditional journalistic forms or formulae. (Shaffer, 2005, p. 25)

Shaffer and Hatfield's work is important in identifying how the "epistemic frame" of journalism community members--interconnected skills, knowledge, identity, values, and epistemologies-can be developed through a carefully designed and guided set of activities involving youth in the writing of science news. In follow-up interview studies, Hatfield (2011) found that youth retained their journalistic skills, knowledge, identity, values, and epistemologies three months after the intensive four-week science.net summer camp.

The findings and strategies of these other researchers on reading and writing science news for learning inform our work in SciJourn.

\section{Summary}

Quality science journalists are a promising model for a scientifically literate populace, but quality science journalism is increasingly difficult to locate amid the explosion of information available in our society through increasingly internetworked sources. Our strategy in SciJourn has been to examine the habits of thought and skills that good science journalists enact, and draw from them a set of practices that our youth and adult citizenry can make use of in their personal lives and in democratic processes. We will now more fully explicate those practices.

\section{SELECTED PRACTICES OF SCIENCE JOURNALISM AS A BASIS FOR SL}

Based on our own expert studies, the literature from the field of journalism, and testing with educators, the SciJourn research group has specified five practices professional science journalists use when writing science news that can be adapted for young people in organized learning environments. The SciJourn science news article writing criteria were developed over a 
period of years using an iterative process. The original version was first offered in 2010. An elaborated description of the current criteria can be found in (Saul, et al., 2012) or on the project website, scijourn.org. These criteria can guide instruction for these five practices, which are all present in quality science news writing but also relate to practices that students could make use of outside school, in their encounters with science in everyday life. Thus, associated with each writing practice is an element of SL for competent outsiders (Polman, et al., 2010; Polman, et al., 2012; Saul, et al., 2012). Table 1 shows the science news writing criteria and the associated SL goals.

\section{TABLE 1}

\section{SciJourn Writing Criteria and Associated Science Literacy Criteria}

\begin{tabular}{|l|l|}
\hline $\begin{array}{l}\text { A science news article is a tangible display of } \\
\text { science literacy. A student reporter is expected } \\
\text { to: }\end{array}$ & A scientifically literate person can ... \\
\hline $\begin{array}{l}\text { Present the personal or local impact of a timely, } \\
\text { narrow, focused topic of interest to the audience } \\
\text { from a unique angle. }\end{array}$ & $\begin{array}{l}\text { Establish the relevance of science/technology } \\
\text { information to their own and others' lives. }\end{array}$ \\
\hline $\begin{array}{l}\text { Search effectively for and recognize relevant, } \\
\text { credible information sources, especially on the } \\
\text { Internet. }\end{array}$ & $\begin{array}{l}\text { Search effectively for and recognize useful STEM } \\
\text { information from credible sources, especially on } \\
\text { the Internet. }\end{array}$ \\
\hline $\begin{array}{l}\text { Write articles based on multiple, credible, } \\
\text { attributed sources. }\end{array}$ & $\begin{array}{l}\text { Utilize multiple, credible sources, and be able to } \\
\text { attribute the expertise and/or perspectives } \\
\text { provided by those sources. }\end{array}$ \\
\hline $\begin{array}{l}\text { Contextualize scientific information, discoveries } \\
\text { and technologies; note broader implications and } \\
\text { reflect on past and future understandings. }\end{array}$ & $\begin{array}{l}\text { Contextualize new STEM information in terms of } \\
\text { societal impact or import and in terms of what is } \\
\text { already scientifically established or tentative. }\end{array}$ \\
\hline $\begin{array}{l}\text { Communicate information that accurately } \\
\text { represents up to date science and forefront the } \\
\text { most important elements. }\end{array}$ & $\begin{array}{l}\text { Make sense of and accurately relate the important } \\
\text { scientific concepts and practices in STEM news. }\end{array}$ \\
\hline
\end{tabular}

${ }^{a}$ Among others, Hurd (1998) has pointed out that the sciences and technology are to a large extent intertwined in current practice. We follow him in referring to the combination as "science/technology," which aligns with the "ST" in the contemporary acronym used by the National Science Foundation and others (STEM, or science, technology, engineering, and mathematics).

\section{A COMPARISON OF EXPERTS TO NOVICES}

The importance of gaining some expertise in the kinds of thinking we stress is made more clear through an overview of some background data from SciJourn. In order to measure SL as outlined in the criteria shown in Table 1, Farrar (2012) created an assessment that focused on skills that a student could apply to science and technology information. The Scientific Literacy Assessment instrument consists of four sections evaluating distinctly different modes of information (a news story, a photo series with caption, a simulated health brochure, and a PowerPoint presentation slide). The assessment was given to experts consisting of science educators, science education researchers, and scientists $(n=18)$ and high school student novices $(n=100)$ in an attempt to establish a landscape of SL skills associated with the SciJourn criteria.

Analysis of the expert and novice responses to the assessment indicated some striking differences in how these groups approach scientific information. Prior to participation in science journalism, $80 \%$ of students asked about how they would learn more about the topics diabetes, high blood pressure, the Deepwater Horizon oil spill, and a volcano ash plume most commonly 
state that they would rely on only one source (Farrar, 2012). However, $66 \%$ of experts refer to multiple sources, most commonly government sites, which represent consensus panels and scientific peer review (thus increasing their credibility). The most common sources named by teens before they participate in our program are non-science individuals with a direct experience of the phenomenon. Both novices and experts make relatively frequent mention of sources in applied fields, such as engineering and medicine. Figure 1 shows words in sources used by experts, and Figure 2 shows words in sources used by novices, across all responses, with greater frequencies shown as larger text.

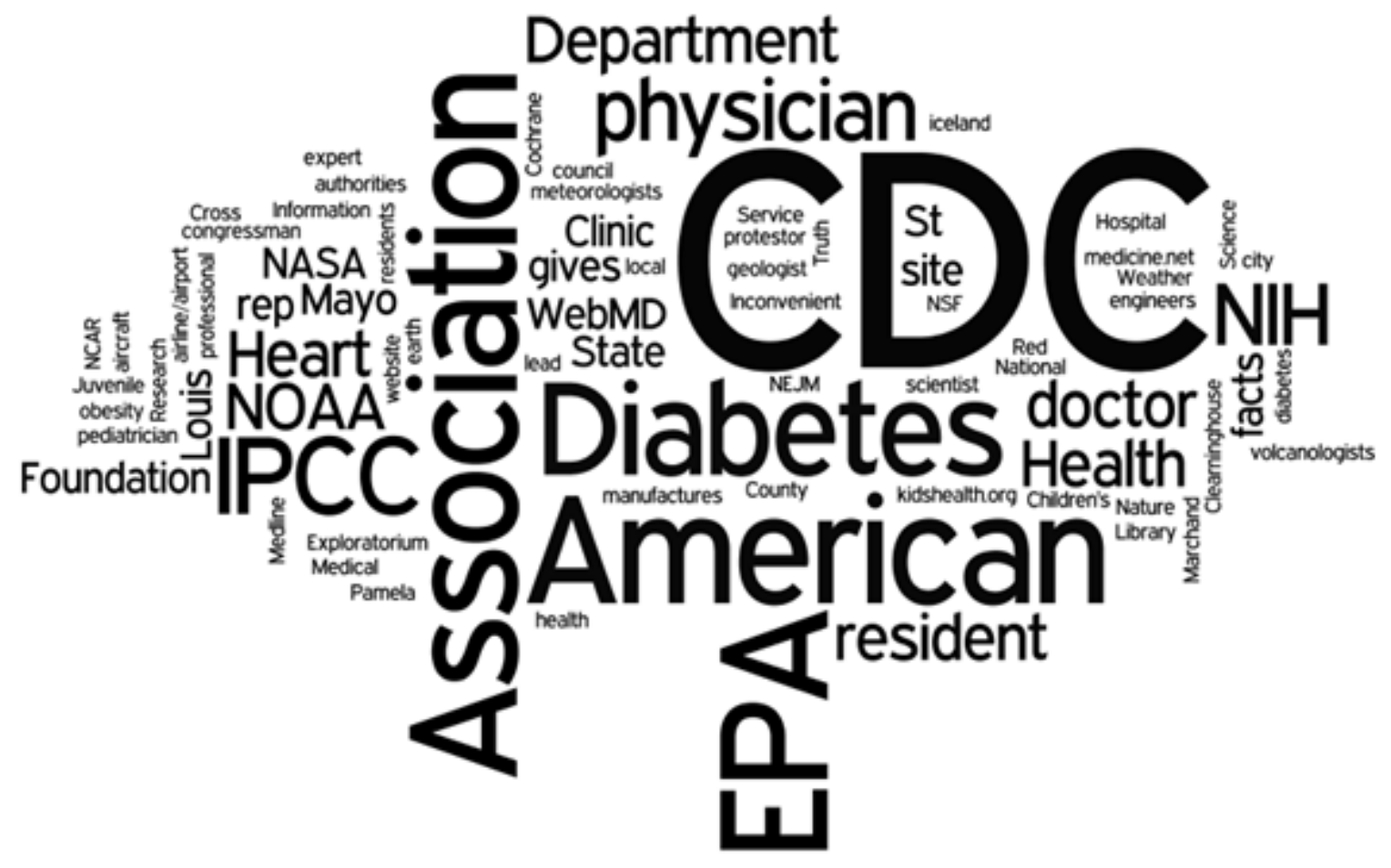

Figure 1. Words in sources named by experts $(\mathrm{n}=18)$ to learn more about the topics of diabetes, high blood pressure, the Deepwater Horizon oil spill, and a volcano ash plume. 


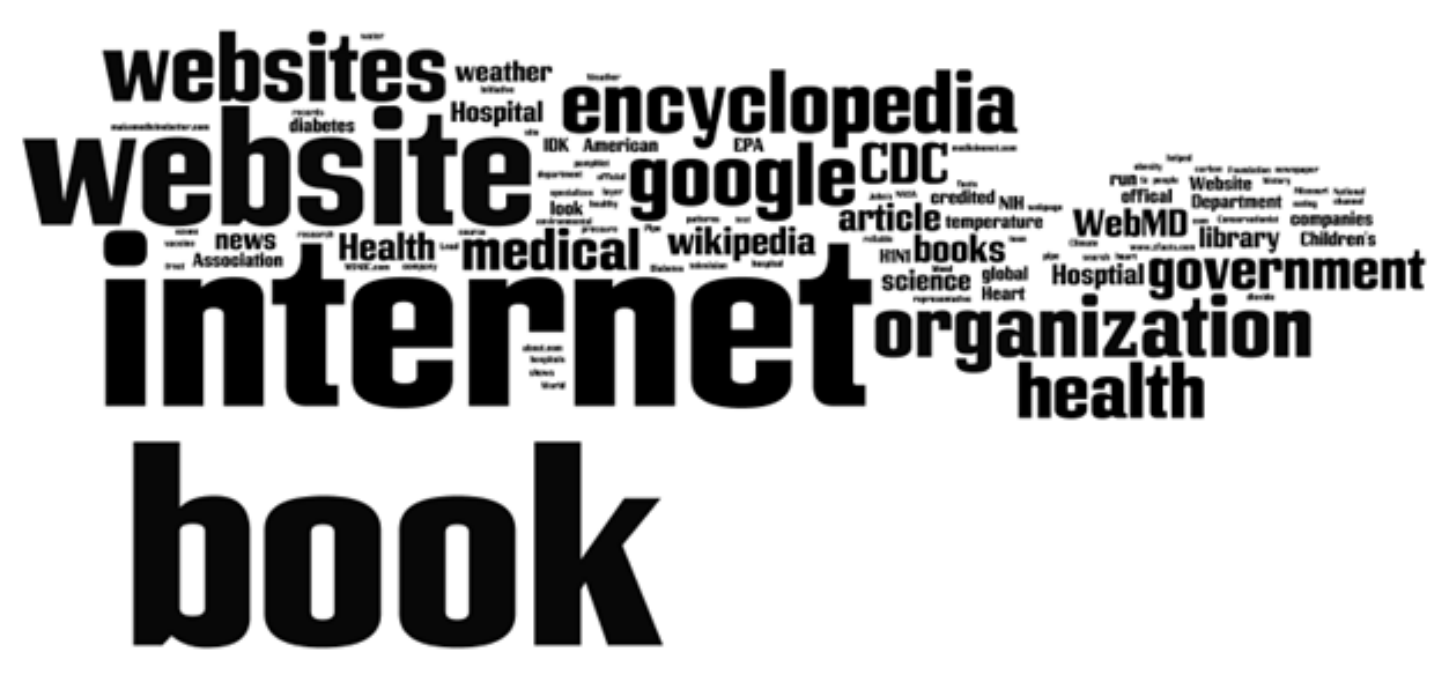

Figure 2. Words in sources named by novices $(n=100)$ to learn more about the topics of diabetes, high blood pressure, the Deepwater Horizon oil spill, and a volcano ash plume.

\section{DESIGNING AND RESEARCHING AN ENVIRONMENT THAT SPONSORS SL THROUGH JOURNALISM}

In this section, we will discuss the distributed learning environment we designed to "sponsor" (Brandt, 1998) the kind of SL we are targeting.

Our learning environment design and research are based on sociocultural and practice theories. Practice theory examines how participation in social practices produces and reproduces the social order, through changes in the identities of persons and knowledgeable skills in practice (Lave \& Wenger, 2005, p. 143). Our sociocultural approach to designing learning environments and researching their lived enactments is most heavily influenced by Wertsch $(1991,1998)$, who stresses that all actions are mediated by cultural tools (or mediational means) that have individual, social, and cultural histories, and by practice theory, which stresses that sets of actions are assembled into regularized practices in communities (e.g., Wenger, 1998). We see interests in actions and practices as triggered in situations (Renninger, 2009) with particular conditions (Azevedo, 2011), such as the opportunity youth in this study had to write science news stories about topics that they found personally relevant. Persistent interests result in sustained engagements in actions and practices over time that present rich opportunities for learning (Azevedo, 2004, 2011; Barron, 2006; Renninger, 2009).

In the context of science education, Roth \& Lee (2004) have referred to this idea through the notion of "science literacy as/for participation in community". The individuals interacting in learning environments belong to multiple communities of affiliation and practice, and their past, present, and expected future identifications with those communities strongly influence their stance toward their actions (Gee, 2000; Nasir \& Hand, 2008; Nasir \& Saxe, 2003; Polman \& Miller, 2010; Wenger, 1998; Wortham, 2006). We follow Dreier (2000) and Wortham (2006) in considering how particular events relate to longer-term trajectories of identification. One way changes in trajectories of identification happen is through shifts in how people position 
themselves with respect to a community, and how they are positioned by others with respect to a community (Davies \& Harré, 1990; Polman \& Miller, 2010).

This theoretical orientation has led us to design a learning environment that enables what some researchers have referred to as "connected learning":

learning that is socially embedded, interest-driven, and oriented toward educational, economic, or political opportunity. Connected learning is realized when a young person is able to pursue a personal interest or passion with the support of friends and caring adults, and is in turn able to link this learning and interest to academic achievement, career success or civic engagement. (Ito, et al., 2013, p. 4)

The physical and psychological context in which actions take place matters to participants' learning experiences, so we consider where learners and others interact and act as contributing to their significance (Wertsch, 1998). We understand particular school or out of school learning environments as existing within larger ecological systems of activity (e.g., Cole, 1996). Another way to say this is that particular people and institutions become "sponsors of literacy" for the next generation (Brandt, 1998) — for instance, older relatives, teachers, priests, and the institutions where they work. Brandt deliberately chose the word "sponsor" because of its association with commercial sponsorship, to reinforce how economic and commercial interests are embedded in sponsored practices of literacy in general.

Good science education instruction organized around Vision I SL sponsors a focus on how science is understood by insiders, through reading, writing and communicating in the manner that scientists themselves do (e.g., O'Neill \& Polman, 2004). Notwithstanding the well-known power issues and discursive complications of widening the access to science careers (e.g., Lemke, 1990; Carlone \& Johnson, 2007), an implicit message such sponsorship can send is that young people who don't intend to pursue science and technology careers may not have use for the practices sponsored in science classrooms. Relatedly, we do not believe practices inspired by science journalism should be sponsored in science classrooms in order to prepare young people for journalism careers. In order to address this concern with respect to science journalism, we have explicitly tried to create a "hybrid" space (Calabrese Barton et al., 2008; Gutiérrez et al., 1995; Gutiérrez et al., 1999) encouraging hybrid culture and practices. Such hybrid spaces that invite cultural practices and identifications from home and community, while providing supportive environments for engaging with professional practices and communities, have elsewhere been shown to foster learning and changes in identification (Calabrese Barton et al., 2008; Gutiérrez et al., 1995; Gutiérrez et al., 1999).

In this $R \& D$ project, we sought to develop a hybrid learning environment that was inspired by expert professional journalism practices, but not hemmed in by them, and an environment that fostered learning, but was not defined by usual school practices and school culture. Some of these activities, such as conducting "fishbowl" pitch sessions and interviewing stakeholders and experts, were developed in the informal science environment, and then transported to the schools. Other activities, such as "readaloud-thinkalouds" where teachers reveal their critical reading and metacognition while examining a contemporary science news article, were developed initially in the schools and subsequently adapted in the informal science environment. While involving youth in journalism practices, we have sought to maintain "emergent authenticity" (Rahm, Miller, Hartley, and Moore, 2003) in which we built on the authentic engagement our participants collaboratively created. 
A unique aspect of this system is the infrastructure for participants to engage in authoring science news centered around a rigorous publication venue valued by community participants. Youth participants follow an authoring process, where they pitch, research, draft, and ideally revise original science news stories. The science news publication venue, called SciJourner, is published on the web (www.scijourner.org) and in a glossy print newspaper format. The managing editor of SciJourner is the second author, a PhD chemist who worked for two decades as a science news editor with the American Chemical Society. Newman maintains rigorous editorial standards, with two goals for SciJourner: publish high quality science journalism by and for teens, and develop the science literacy of participating reporters. The editorial process involves supervisors in the ISE and teachers in the schools submitting articles they wish (they submit a selected number to the editor by email attachment; the editor then marks up the draft using Microsoft Word's "Track Changes" feature, focusing largely on content rather than grammar and style; teachers and sometimes peers assist one another in preparing revisions of the articles; teachers and supervisors do not usually require participating youth to do more than one revision, but most students who are willing to do a second or third revision are able to complete an article published online (see Kohnen, 2012, 2013d). Newman often states that the key to publication is tenacity (persistent engagement).

The distributed activity system built around the educative production of science news is providing a rich context to further develop and refine our models. From 2008 to 2012, SciJourn included diverse groups of learners facilitated by three program facilitators at an informal science education (ISE) program and 43 teachers at 25 middle and high schools and across a metropolitan region in the Midwestern United States; since then, a statewide initiative has been undertaken elsewhere, and workshops have introduced the model at conferences. The ISE site was a youth development initiative administered by a large community-based organization that runs an intensive summer series and a Saturday academic year program for students between the summer before $9^{\text {th }}$ grade, and the summer after $12^{\text {th }}$ grade. This site allowed a smaller number of youth to engage over a period of years in hybrid journalism activities, developing and deepening new forms of participation and identification. See Polman \& Miller (2010) for further information on this program. The SciJourn school sites ranged geographically across urban, suburban and rural locations; the schools were mostly public but a few were private parochial. The schools served socioeconomically diverse students as well-they ranged from quite affluent to severely economically challenged. The implementation of teachers at diverse school sites have allowed us to compare various forms of implementation. Assessments based on the above framework for science literacy have shown learning gains, with students' engagement in writing and revision both contributing to greater learning gains (Farrar, 2012), and we have been able to examine some of the dynamics of work involving the cultures of teaching and journalistic editing (Kohnen, 2013a) and authenticity (Kohnen, 2013c).

Based on our theoretical orientation, our professional development model is developmental and dialogic, inviting teachers to adapt the model described above to their context (see Kirshner \& Polman, 2013). In each year of the project, cadres of teachers participate in a 2-week intensive summer professional development program in which they wrote science news articles themselves under the guidance of an experienced science news editor, revised their work and worked with our faculty and graduate students to prepare and co-develop instruction incorporating the reading and writing of science news into their own classroom practices. 


\section{EDUCATIVE SCIENCE JOURNALISM PRACTICES AND SCIENCE LITERACY}

In this section, we discuss each of the five criteria that we have used to evaluate student writing, with an explanation of their meaning and significance, and examples of how science journalism practices contributed to fostering SL for competent outsiders in ways that are often strikingly different from "science education as usual." The examples are drawn from the implementation of SciJourn in 26 high and 8 middle school contexts by 53 teachers between 2009 and 2011, and one out of school program. A variety of studies were conducted in these classrooms, and are detailed elsewhere (Farrar, 2012; Hope, 2012; Kirshner \& Polman, 2013; Kohnen, 2012, 2013a, 2013b, 2013d; Polman, et al., 2010; Polman \& Hope, 2014). Observational records collected by four observers in selected classrooms and professional development sessions, archives of all science news story drafts submitted to the university-based editor, and interviews of selected students and teachers served as data sources for these examples.

\section{Relevance}

Establishing personal relevance, or making connections to one's life and interests, is at the heart of SL; if students see scientific information as useful in everyday life, they are motivated to learn and understand it. As Feinstein put it, "learning about science in a deeply personal context could make students more willing to plunge into unfamiliar, science-tinged waters in the future" (2011, p. 282). Cognitive science and educational research stresses that personal meaning and significance, within sociohistorically interpreted situations, drives learning (e.g., Bransford, Brown, and Cocking, 2000). This contrasts to approaches where lists of conceptual knowledge and facts are learned "just-in-case" they will be useful in the future (e.g., Trefil, 2008) and the content knowledge portions of the previous generation of national science education standards (NRC 1996) as well as the new framework (NRC, 2012b). Aikenhead et al. (2011, p. 31) has called such content knowledge standards the "wish-they-knew" approach to science education.

Too often in science classrooms today, what is learned is not seen as relevant by students, or connected to their lives beyond the classroom. In contrast, reporters and their editors need to address the interests and point of view of their audiences (e.g., Shute, 2006) and stress its meaningfulness and relevance (Gregory \& Miller, 1998), so science news stories build on the fact that science and technology affect each of us personally. We have found that many middle and secondary school teachers are eager to increase students' sense of the connections between their science classes and their lives. Teachers in SciJourn typically introduce the notion of narrow, focused contemporary science news to the subject of their class - whether it be chemistry, life sciences, or environmental science-through readaloud-thinkaloud activities connected to their curriculum. In a readaloud-thinkaloud, teachers reveal their thinking in the course of reading an article, stressing their own critical sense-making processes (for further details, see Saul et al., 2012, pp. 55-66). Once the focus turns from reading to writing, we encourage students to focus on their interests and lives, helping them research the most credible science and technology for stories that are aimed at people like themselves - other teens.

Even with our initial framing discussions and readaloud-thinkalouds, students writing their first drafts of science news stories often bury or downplay the personal relevance and local connections to their topic. Perhaps, based on prior school experience, students at first show reluctance to put out the unique personal or local angle. But as Shaffer's study showed (2005), journalists "writing for story" often reach universals that readers can relate to through the stories 
and selected details of particular individuals whom they have encountered; Gregory \& Miller (1998) also discuss how journalists use personalization to make their news stories more engaging. The SciJourner science editor ends up encouraging students to make their stories relevant to readers by beginning the story with a lede in a "nut graph" about a personal health issue faced by a family member or neighbor, or a public concern at their school or in their nearby community, or even a timely sports victory. Early in our project we tried having students write the lede first and it did not work because they could not identify the salient points before drafting the full story. We later went to having students write their stories, and often the teacher or editor pointed out what would serve best as their ledes. The personally relevant portions of their stories were often tucked in near the bottom of their first drafts, and we seek through the revision process to help students see that their stories and the science are inextricably linked.

Students in SciJourn have built stories around:

- Diseases and health conditions which affect themselves, family members, or neighbors, as well as associated treatments ("Quitting 'Cold Turkey': What Your Body Goes Through", about quitting smoking; "Immigration and Living with Type 2 Diabetes"; "Ever Heard of Alternative Medicines?")

- Sports ("The Secret to Saving a Penalty Kick"; "Playing in Blood, Sweat and Saliva", about Astroturf fields like the one planned for the reporter's school; "The Science behind Baseball", discussing the physics of hitting and pitching in the major leagues)

- Environmental issues in their school or community ("Watch Out for Mold", about building mold in a local apartment building; "How Green is Your School?")

- Technology that students find interesting/useful ("Cochlear Implant Controversy"; "Video Games and Science")

• Teen-related issues ("Thinking about a Tattoo"; "Smoking... Smarties?"; "Text Your Neck Off"; "Childhood Obesity?")

- And just curiosity ("Sharks Attack"; "Stay Away from the Full Moon"; "When Good Makeup Goes Bad").

Consider the "Thinking about a Tattoo?" and "Watch Out for Mold" articles. Personal consideration of tattoos is salient to many teens, including the writer of that particular article. Whereas many organized learning environments focused on science would not have welcomed tattoos as a topic, writing a science news story provided a context for a teen considering a tattoo to explore the health risks of tattooing, and safety measures of professional tattoo artists and technology, and led to learning about professional credentialing. For the "Watch Out for Mold" story, a young man focused on an apartment building in his local community that had been closed due to mold damage. The public and personal consequences of mold in buildings, and the science behind it, were approached through this angle. Our research on variation in student engagement confirms our expectation that students given more freedom to select topics they see as relevant engage more strongly with the science (Hope, 2012; Polman \& Hope, 2014). In addition, the experience of exploring the usefulness of science and technology information to personal and public concerns within the science news stories young people write may plant the seeds of habits of mind we hope they will use later in life. If students have no experience figuring out the connection of their own or their community's concerns to cutting-edge science, then how can we expect them to make such connections long after they leave school? 
In addition, students may find some science inherently fascinating, and thereby relevant to their interests; students who have a personal interest in the topics have written stories about ocean acidification, dinosaur feathers, and using silicon nitride instead of titanium for bone implants.

\section{Search}

Students' search, identify and interpret relevant scientific and technical information to craft science news stories; this is similar to the kinds of search and interpretation moves that adult citizens will need to do when they make use of SL in action in their future lives, where the topic drives the need to learn about the science/technology (Aikenhead, et al., 2011; Feinstein, 2011; Feinstein et al., 2013). Our hope is that the ecological validity of the instructional context to possible future action makes citizen science news reporting a more adequate preparation for future learning (Bransford \& Schwartz, 1999).

The experience of a young man writing a story about quitting smoking provides an example of how young people who write science news stories can enhance their skills at searching for science information. His unique angle on the story was the experience of his grandfather, who called it "the hardest decision" of his life. In the first draft of the story, the only sources for information he referred to were his grandfather for his experience, and a website he referred to as "Healthbolt.com" for the immediate effects of quitting on the human body ("in 20 minutes, your blood pressure will return to normal"). His grandfather was a relevant stakeholder, ${ }^{2}$ but his source for the health information had questionable credibility.

Many adults and children today begin searches for general science and health information on Wikipedia or a search engine. Wikipedia is considered anathema in most schools, but this is probably the student's original source of the information that "in 20 minutes your blood pressure will return to normal" (see Wikipedia, 2012). If the student did use that source, her teacher must not have yet encouraged her to use Wikipedia the way we suggest, as a "good place to start a search, but a lousy place to end" (see Saul et al., 2012, pp. 87-101, and the student guide on the companion website teach4scijourn.org). One of our recommendations is to use Wikipedia to identify useful scientific terminology that may lead to more expert search results; this is particularly apt in science and medicine, fields that research shows have highly accurate Wikipedia entries (e.g., Clauson, Polen, Boulos, Dzenowagis, 2008; Giles, 2005). In the case of quitting smoking, the term "smoking cessation" could be picked up from the Wikipedia entry; in the case of "life on other planets", Wikipedia introduces the terms "extraterrestrial life", and "astrobiology". Such terms are more useful search terms for finding scientific information on the web than more colloquial terms, which often yield hits on fictional or creative websites. Our second recommendation is to check the external links cited in Wikipedia footnotes for credible sources. In this case, the American Cancer Society (ACS) was cited on the smoking cessation Wikipedia page for the blood pressure change. But the student cited "Healthbolt.com". Why? We do not have interviews of him, but he may have believed it was more acceptable than Wikipedia. Second, "Healthbolt's" popularity as a health blog in general, and the popularity of the blogger's infographic on quitting smoking, would have created a high Google ranking for that source. Thus, when the student searched for the topic in 2010, he would have gotten a hit on the blog entry "What Happens to Your Body If You Stop Smoking Right Now?" by blogger Wade

\footnotetext{
${ }^{2}$ There is more information on stakeholders below, in the section on multiple, credible, attributed sources.
} 
Meredith (the URL for Healthbolt was actually http://healthbolt.net at the time of the student's search in 2010, but the site has since been absorbed by the blog aggregator Blisstree, which is at http://blisstree.com. See Meredith, 2010).

Searching and selecting science information specifically in the $21^{\text {st }}$ century involves understanding the benefits and limitations of crowdsourcing, social media, and the increasing availability of government and professional organization information. Popular blogs and Wikipedia entries are likely to come up among the top results in general searches related to topics that concern the public, and scientifically literate citizens need to both consider what such sources have to offer, and know how to move beyond these to more specialized sources. But locating and selecting information is not the end of information fluency-how those sources of information are used is crucial, and addressed by the next standard.

Our approach to searching is built on the idea that students should be skeptical of all sites and learn to decode what is credible by reading the About Us or recognizing the science agencies or science-vetted sites, such as National Institutes of Health (NIH), American Diabetes Association, Mayo Clinic and even ESPN sports science, that set a higher standard, because they represent more scientific consensus, greater emphasis on peer-reviewed findings, and contributions of more highly credentialed individuals. As Chinn, Buckland, \& Samarapungavan (2011) would put it, we have reason to find the testimony of such sources more trustworthy.

\section{Multiple, Credible, Attributed Sources}

The first draft of the story on quitting smoking also exhibited a limitation that many young people share: not using multiple credible sources. When expert science journalists write stories, they make sure to access multiple sources that are credible for the purpose they serve, and then attribute what qualifies those sources in their news stories. In school, the primary information sources students use - textbooks - do not generally attribute the sources of information they include; press releases often do not either. In journalism, phrases like "according to" an organization or individual, or "so and so tells New York Times" might appear to just be conventions for journalists writing in the genre of science news, but they underlie a sophisticated understanding of the science information landscape which experts develop (Shute, 2006; Yam, 2006). The author of the quitting smoking story got valuable input from the SciJourn science editor in order to move beyond his initial use of "Healthbolt.com". In his feedback to the author $^{34}$, the editor wrote: "Get better sources and get more of them", and referred to American Cancer Society (ACS), the Centers for Disease Control (CDC), NIH, Mayo Clinic, and WebMD as possibilities. To the uninitiated, these acronyms are alphabet soup (and some of our students in high school classes seriously think "Mayo" is a joke referring to mayonnaise). The editor continued by saying, "I'm willing to bet that Healthbolt 'stole' their information from ACS."

Neither the student nor the editor could tell where the blogger at Healthbolt got her information, because that blogger was not following the journalistic convention of attribution (see Meredith, 2010). Neither did the blogger make clear that she was using multiple credible sources. But the student who revised his story learned to do both these things, before the story could be published. Sure enough, the ACS (American Cancer Society; 2012) has a page which states "20 minutes after quitting your heart rate and blood pressure drop" and attributes this information to a peer-reviewed scientific article "Effect of smoking on arterial stiffness and pulse pressure amplification, Mahmud A, Feely J. Hypertension. 2003:41:183." In his second draft, the

${ }^{3}$ For more information on editor feedback in this kind of context, see Saul, et al., 2012. 
student attributed two statements of the health effects to the ACS, and two other statements to the CDC - one about the extent of smoking in the U.S. (which contributes to contextualization, as described below).

As the above descriptions indicate, the activity of writing science news stories with multiple, credible sources scaffolds broadening and deepening the appreciation of where science information can be found, at the same time it reinforces the need for corroboration.

The explicit consideration of both expertise and bias in individual and organizational sources (Gregory \& Miller, 1998; Manjoo, 2008; Postman, 1992; Shute, 2006; Yam, 2006) is also scaffolded by the conventions of attribution in news writing. The student who wrote the building mold story reflected an appreciation of the study of that specific scientific topic and how credibility is built up within the scientific scholarly community when he wrote, "According to Nicholas P. Money, a Ph.D. in mycology and author of Carpet Monsters and Killer Spores, 'mold initiates infections mainly in people with damaged immune systems'." In addition to paying special attention to the testimony (Chinn, et al., 2011) of experts with scientific credentials and peer review, we have found it necessary to remind learners of the experiential knowledge of broader applied professionals (e.g., car mechanics, credentialed tattoo artists) and stakeholders (e.g., family members or neighbors affected by a health condition, athletes injured playing a sport, or community members and students at a school potentially affected by an environmental problem or its abatement). Although interviews are difficult to fit into the resource and time constraints of formal K-12 schooling, they are valuable tools for accessing multiple perspectives on scientific and socioscientific issues. As researchers (e.g., Kelly, 2011; Roth \& Lee, 2004) have noted, for scientifically literate adults, knowledge is "in the community" even more than it is already in any one person's head. But in order for the knowledge in the community to be useful for students today and in their futures, they need to broaden the communities with which they connect either locally or through the Internet. They also need to know how to interact with the members of those relevant communities, as well as make sense of the discourse in the information and media those communities create (Kelly, 2011). Synthesizing the range of relevant perspectives on an issue - with the grist provided by these multiple credible sources - is an important vehicle for deepening understanding of the science and its impact, which are the next two criteria.

\section{Contextualization}

Journalists are deeply concerned about two forms of contextualization, which they ideally investigate when crafting stories for their readers. First, journalists have an obligation to present why the information in an article is important from a scientific viewpoint; second, they need to contextualize the societal impact and import of the news being reported in the story.

In order to be contextualized in the scientific field, information in science news stories should report relevant background science (Evans, et al., 1990; Gregory \& Miller, 1998; Manjoo, 2008; Shute, 2006; Siegfried, 2006), and it should be communicated accurately, concisely and precisely (our editor is always pushing for numbers in these stories). Additionally, good science journalists both understand and convey important aspects of the nature of science (Blum, Knudson, \& Henig, 2006); such concerns are familiar to researchers in science education who have been advocating for focus on teaching the nature of science (e.g., Lederman, 1992). Specifically, it is important for science journalists to convey to readers how science research progresses and accumulates over time, with disagreements and consensus playing important roles, leading to some areas of science more settled and others contentious and tentative (e.g., 
Blum, Knudson, \& Henig, 2006; Cope, 2006; Shute, 2006). Importantly, good science journalism does not utilize a "courtroom epistemology" (Schneider, 2009). The perceived and some would say "manufactured" controversies over smoking and cancer in the 20th century and climate change in the early $21^{\text {st }}$ century (e.g., Michaels, 2008; Seethaler, 2009) have clearly demonstrated that "two sides" of an issue are not always equally supported by credible scientific research.

In order to be contextualized in terms of impact and import for society, science news stories should include reporting on why the science matters to people, and the scope of the issue or concern. In order to communicate how many people are or could be affected by the science or technology in a story, a journalist needs to consider and understand scale. These are issues of concern in science and mathematics education focused on conceptual understanding and data analysis, but the insights of research and development on science, technology, and society (STS; e.g., Kolstø, 2001) as well as socioscientific issues (e.g., Zeidler \& Sadler, 2011) in education also have important contributions for SL. For students writing science news, presenting the broad significance (Blum, Knudson, \& Henig, 2006; Siegfried, 2006) and big picture risks (Schneider, 2009) related to a story are important elements of a journalist writing as a watchdog (Hatfield \& Shaffer, 2006). The public service and watchdog purposes of journalism can be highly motivating for young people.

The experience of a young woman who wrote about the alternative medicine practice of "cupping" serves to illustrate how journalistic writing can contribute to SL in terms of scientific contextualization. Cupping is a procedure "in which a rounded glass cup is warmed and placed upside down over an area of the body, creating a suction that holds the cup to the skin" (quoted from student news story). This story was relevant to the student because it related to a cultural practice advocated by her grandmother, which the student personally found reduced the severity of her own chronic headaches. In the first draft of this story, the student described only positive claims about the efficacy of this and other alternative medicine practice, making claims that were unattributed to sources. She made statements such as "Scientists are finding", and "It is believed". She made unsupported claims, like "aromatherapy, acupuncture, and etc. are known to work, but like everything else in the world, people like it and dislike it." Thus, the student did not contextualize her statements about cupping in any specific science studies, or explicate what is emerging or established science. In his response to her, the editor stressed, "You ... need to attribute your information to credible sources. You can't just make statements", and sprinkled the article draft with challenges of "According to who?" (three times) and "Says who?" (three times as well). In response to the student's assertion that "It is believed that these medicines are becoming more popular because scientists have finally come to their senses that nature's remedies are the best" the editor replied, "Are you just making this up or did you find sources that say that?" He stressed, "I don't want you to advocate for or against alternative medicines ..."

In her first revision, the student reorganized and removed some content, and added the perspective of a credentialed scientist on the practice: "Professor Edzard Ernst of the department of complementary medicine at the University of Exeter says that 'cupping could cause burns' and 'there is no evidence for its efficacy."' She concluded this draft with the statement, "I'd encourage this to anyone seeking natural, alternative treatments, but I'm not guaranteeing that it'll be the best decision you've made for yourself."

Interestingly, the student had neglected some of the science in support of alternative medicines in this revision, so needed some encouragement from the editor and her teacher to seek out credible sources supporting alternative medicine practices, and include them in her next 
revision. Her third revision included reference to the National Center for Complementary and Alternative Medicine (NCCAM), which is part of NIH, and to research cited by that body on cupping's positive efficacy. This revision also referred to findings of an allergist from the American College of Allergy, Asthma and Immunology (ACAAI) in Phoenix.

Scientific contextualization such as that cited by the author of this science news article on alternative medicine is important in today's world, where science and technology developments and claims are often distorted or misused for the sake of political or economic gain (Michaels, 2008; Seethaler, 2009). In addition, societal contextualization is necessary, particularly as it relates to risk (Gregory \& Miller, 1998). A big portion of this is in relating who is or might be affected by the science or technology discussed in the story. For instance, the author of the quitting smoking story stated, "According to the Centers for Disease Control and Prevention (CDC), approximately 46 million U.S. adults smoke, as of 2009. Smokers aren't the only ones that can get sick from, or even killed by, nicotine. Nonsmokers can experience similar symptoms to those who smoke." In the building mold story, the author had a clear message that all citizens need to be aware: "The U.S. Environmental Protection Agency (EPA) and the Department of Agriculture state that everybody is at risk for mold poisoning." Because societal contextualization is so often related to the scale, extent, or cost of a phenomenon, it lends itself to quantitative representation in information graphics, which are an increasingly common form of web-based science news; we are examining the learning potential of journalistic infographics in current exploratory research (Lamb et al., 2014; see science-infographics.org).

\section{Sense-Making/Factual Accuracy}

Of the five criteria for SL, the idea of sense-making, exhibited through attaining what good science journalists refer to as "factual accuracy" (Gregory \& Miller, 1998), is perhaps most directly related to typical science education practices. Decades of research on building conceptual understanding, as well as numeracy and using graphical and visual representations, apply to this arena. The challenge that journalists face in their profession do offer some important lessons and provide an important backdrop for the kind of scientific sense-making citizens need. Journalists and practitioners of a few other professions, such as museum exhibit developers, have to learn to be expert generalists when it comes to the subject matter content of their materials. Writing to formula (Hatfield \& Shaffer, 2006) in science news stories means focusing only on the most essential, up to date and central points, rather than distracting details. The research on writing to learn in the disciplines provides insights into how such processes can drive understanding; for instance, the translation of ideas for an audience can help students make deeper sense of the science involved (Hand, Eun-Mi, \& Bruxvoort, 2006).

With the capabilities for "cut and paste" in today's networked computer environment, it is vital that students process information, and the norms of journalism provide both ethical and discursive norms for referring to and summarizing ideas. The student who wrote about building mold synthesized a good deal of science content in order to clarify the science for an audience:

Mold is a fungus that grows in multicellular filaments. According to the EPA, mold grows on various kinds of damp or decaying organic matter. People are at risk anytime, because mold is floating in the air and so small you cannot see them until they build up like a colony. Mold needs certain things in order to form: water, food, suitable air quality and temperature. Mold forms in places such as food, walls, or any place where it's moist, hot, and humid. 
Because of the challenge of learning enough science to make sense of new developments, we have found that the support of teachers and editors with strong content knowledge is necessary (see Kohnen, 2013b, 2013c), and that the journalistic tool of interviews is a strong asset for fostering learners' understandings, because it provides an opportunity for individuals who have research-based or clinical knowledge, as well as relevant experiences, to mediate the ideas and interactively answer questions the learners may have. As previously noted, making the space for journalistic interviews is not easy in K-12 education, but has strong benefits.

\section{CONCLUSIONS}

In this essay, we have tried to demonstrate how five practices adapted from science journalism encompass much of what a student needs to be able to do in order to make decisions while answering questions about science topics. The consideration of how to cultivate contexts for building SL such as that advocated above demand that we consider the research and development needed.

Decades of research and development have been devoted to designing learning environments to foster Vision I SL, and to evaluate and research their efficacy and qualities. We are gratified to be among those investigating how to cultivate Vision II SL for competent outsiders to science, by adapting practices of journalism in education. Jarman \& McClune's designs for critical reading of science news in UK schools, and Shaffer and Hatfield's epistemic game Science.net implemented as a short-term online game with an offline summer camp, provide two useful models for integrating journalism in education. We have now maintained SciJourn for more than six years. In this paper, we have demonstrated the rationale behind and promise of another adaptation of journalism for sponsoring Vision II SL.

Efforts to sponsor SL for competent outsiders are important for future generations. In the long run, multiple strands of research and development will be needed to inform us of how to foster future generations of citizens who find science useful for their everyday lives. We hope the journalism model presented in this essay will inspire further discussion and development related to this important goal.

\section{ACKNOWLEDGMENTS}

This material is based upon work supported by the National Science Foundation under Grant No. DRL-0822354. We wish to thank the SciJourn community, including the teachers, facilitators, and students as well as research and development staff and advisors, for all their contributions to our lives and this work. We especially wish to thank colleagues Cynthia Graville-Smith, Jennifer Hope, Angela Kohnen, Laura Pearce, Nancy Singer, Eric Turley, and Michelle Whitacre; as well as advisors Hubert Dyasi, Kevin Leander, Bill Penuel, Carol Stearns, Brian Hand, and Matthew Benus. 


\section{SCIENCE JOURNALISM FOR SCIENCE LITERACY}

\section{REFERENCES}

Aikenhead, G. S. (2006). Science education for everyday life: Evidence-based practice. New York: Teachers College Press.

Aikenhead, G. S., Orpwood, G., and Fensham, P. (2011). Scientific literacy for a knowledge society. In C. Linder, Östman, L., Roberts, D. A., Wickman, P.-O., Erickson, G., \& MacKinnon, A. (Ed.), Exploring the landscape of scientific literacy (pp. 28-44). New York: Routledge/Taylor and Francis Group.

American Cancer Society (2012). When smokers quit - What are the benefits over time? Accessed March $27,2012$. http://www.cancer.org/Healthy/StayAwayfromTobacco/GuidetoQuittingSmoking/guide-to-quitting-smokingbenefits

Azevedo, F. S. (2004). What does it mean to be interested in a practice? In Y. B. Kafai, Sandoval, W. A., Enyedy, N., Nixon, A. S., \& Herrera, F. (Ed.), Proceedings of the Sixth International Conference of the Learning Sciences 2004: Embracing diversity in the learning sciences (pp. 10-11). Mahwah, NJ: Lawrence Erlbaum Associates.

Azevedo, F. S. (2011). Lines of practice: A practice-centered theory of interest relationships. Cognition and Instruction, 29(2), 147-184.

Barron, B. (2006). Interest and self-sustained learning as catalysts of development: A learning ecology perspective. Human Development, 49, 193-224.

Blum, D., Knudson, M., \& Henig, R. M. (Ed.). (2006). A field guide for science writers: The official guide of the National Association of Science Writers (2nd ed.). New York: Oxford University Press.

Bouillon, L., \& Gomez, L. (2001). Connecting school and community with science learning: Real world problems and school-community partnerships as contextual scaffolds. Journal of Research in Science Teaching, 38(8), 878-898. doi:10.1002/tea.1037

Brainard, C. (2009) Science journalism's hope and despair. Columbia Journalism Review. February $13,2009$. http://www.cjr.org/the_observatory/science_journalisms_hope_and_d.php?page=all

Brandt, D. (1998). Sponsors of literacy. College Composition and Communication, 49(2), 165-185.

Bransford, J. D., Brown, A. L., \& Cocking, R. R. (2000). How people learn: Brain, mind, experience, and school. Washington, DC: National Academies Press.

Bransford, J. D., \& Schwartz, D. L. (1999). Rethinking transfer: A simple proposal with multiple implications. Review of Research in Education, 24, 61-100. doi:10.3102/0091732X024001061

Brossard, D., Lewenstein, B., and Bonney, R. (2005). Scientific knowledge and attitude change: The impact of a citizen science project. International Journal of Science Education, 7(9), 1099-1121. doi:10.1080/09500690500069483

Brown, J. S., Collins, A., \& Duguid, P. (1989). Situated cognition and the culture of learning. Educational Researcher 18(1), 32-42. doi:10.3102/0013189X018001032

Brumfiel, G. (2009). Science journalism: Supplanting the old media? Nature, 458, 274-277. doi:10.1038/458274a

Calabrese Barton, A., Tan, E., \& Rivet, A. (2008). Creating hybrid spaces for engaging school science among urban middle school girls. American Educational Research Journal, 45(1), 68-103. doi:10.3102/0002831207308641

Calabrese Barton, A., and Tan, E. (2010). We be burnin: Agency, identity and learning in a green energy program. The Journal of the Learning Sciences, 19(2), 187-229. doi:10.1080/10508400903530044

Carlone, H. B., and Johnson, A. (2007). Understanding the science experiences of successful women of color: Science identity as an analytic lens. Journal of Research in Science Teaching, 44(8), 1187-1218. doi:10.1002/tea.20237

Chinn, C. A., Buckland, L. A., \& Samarapungavan, A. (2011). Expanding the dimensions of epistemic cognition: Arguments from philosophy and psychology. Educational Psychologist, 46 (3), 141-167. doi:10.1080/00461520.2011.587722

Clauson, K. A., Polen, H. H., Kamel Boulos, M. N., Dzenowagis, J. H. (2008). Scope, completeness, and accuracy of drug information in Wikipedia. Annals of Pharmacotherapy, 42 (12), 1814. doi:10.1345/aph.1L474

Coiro, J. (2003). Rethinking comprehension strategies to better prepare students for critically evaluating content on the Internet. The NERA Journal, 39(2), 29-34. Available: http://ctell1.uconn.edu/coiro/nera2003.pdf

Cole, M. (1996). Cultural psychology: A once and future discipline. Cambridge, MA: Belknap Press of Harvard University Press.

Collins, A., Brown, J. S., \& Newman, S. E. (1989). Cognitive apprenticeship: Teaching the craft of reading, writing, and mathematics. In L. B. Resnick (Ed.), Knowing, learning, and instruction: Essays in honor of Robert Glaser (pp. 453-494). Hillsdale, NJ: Lawrence Erlbaum Associates. 


\section{SCIENCE JOURNALISM FOR SCIENCE LITERACY}

Cope, L. (2006). Understanding and using statistics. In D. Blum, Knudson, M., \& Henig, R. M. (Ed.), A field guide for science writers (2nd ed., pp. 18-25). New York: Oxford University Press.

Davies, N. (2008). Flat earth news: An award-winning reporter exposes falsehood, distortion and propaganda in the global media. London: Chatto \& Windus/Random House.

Davies, B., \& Harré, R. (1990). Positioning: The discursive production of selves. Journal for the theory of social behaviour, 20(1), 43-63.

DeBoer, G. E. (2000). Scientific literacy: Another look at its historical and contemporary meanings and its relationships to science education reform. Journal of Research in Science Teaching, 37(6), 582-601. doi:10.1002/1098-2736(200008)37:6<582::AID-TEA5>3.0.CO;2-L

diSessa, A. A. (2006). A history of conceptual change research: Threads and fault lines. In R. K. Sawyer (Ed.), Cambridge handbook of the learning sciences. Cambridge, UK: Cambridge University Press.

dos Santos, W. L. P. (2009). Scientific literacy: A Freirean perspective as a radical view of humanistic science education. Science Education, 93(2), 361-382. doi:10.1002/sce.20301

Dreier, O. (2000). Psychotherapy in clients' trajectories across contexts. In C. Mattingly, and Garro, L. (Eds.), Narrative and the cultural construction of illness and healing (pp. 237-258). Berkeley: University of California Press.

Duschl, R. A., Schweingruber, H. A., \& Shouse, A. W. (Eds.). (2007). Taking science to school: Learning and teaching science in grades $K-8$. Washington, DC: National Academies Press.

Edelson, D. C., \& Reiser, B. J. (2006). Making authentic practices accessible to learners: Design challenges and strategies. In R. K. Sawyer (Ed.), Cambridge handbook of the learning sciences. Cambridge, UK: Cambridge University Press.

Eisenhart, M., Finkel, E., Marion, S. F. (1996). Creating the conditions for scientific literacy: A re-examination. American Educational Research Journal, 33(2), 261-295. doi:10.3102/00028312033002261

Evans, W. A., Krippendorf, M., Yoon, J. H., Posluszny, P., \& Thomas, S. (1990). Science in the prestige and national tabloid presses. Social Science Quarterly, 71(1), 105-117.

Farrar, C. (2012). Assessing the impact participation in science journalism activities has on scientific literacy among high school students. Doctoral dissertation, University of Missouri-St. Louis. Available: https://apps.umsl.edu/webapps/weboffice/ETD/query.cfm?id=r7382

Feinstein, N. (2011). Salvaging science literacy. Science Education, 95(1), 168-185. doi:10.1002/sce.20414

Feinstein, N. W., Allen, S., \& Jenkins, E. (2013). Outside the pipeline: Reimagining science education for nonscientists. Science, 340(6130), 314-317. doi: 10.1126/science.1230855

Feldman, A., Konold, C., \& Coulter, B. (2000). Network science: A decade later. Mahwah, New Jersey: Lawrence Erlbaum Associates.

Flanagin, A. J. and Metzger, M. J. (2010). Kids and credibility: An empirical examination of youth, digital media use, and information credibility. MacArthur Foundation Report. MIT Press: Cambridge, MA. http://dmlcentral.net/sites/dmlcentral/files/resource files/Kids and Credibility.pdf

Gauchat, G. (2012). Politicization of science in the public sphere: A study of public trust in the United States, 1974 to 2010. American Sociological Review, 77(2), 167-187. doi:10.1177/0003122412438225

Gee, J. P. (2000). Identity as an analytic lens for research in education. Review of Research in Education, 25, 99125.

Giles, J. (2005). Internet encyclopaedias go head to head. Nature, 438(7070), 900-901. doi:10.1038/438900a

Gregory, J. A., \& Miller, S. A. (1998). Science in public: Communication, culture, and credibility. New York: Plenum Press.

Gutiérrez, K. D., Baquedano- López, P., \& Tejeda, C. (1999). Rethinking diversity: Hybridity and hybrid language practices in the third space. Mind, culture, and activity, 6(4), 286-303.

Gutierrez, K., Rymes, B., \& Larson, J. (1995). Script, counterscript, and underlife in the classroom: James Brown versus Brown v. Board of Education. Harvard Educational Review, 65(3), 445-471.

Hand, B., Eun-Mi Yang, O., \& Bruxvoort, C. (2006). Using writing-to-learn science strategies to improve year 11 students' understandings of stoichiometry. International Journal of Science and Mathematics Education, 5(1) 125-143. doi:10.1007/s10763-005-9028-1

Hatfield, D. (2011) The right kind of telling: An analysis of feedback and learning in a journalism epistemic game. (Unpublished doctoral dissertation). University of Wisconsin-Madison, Madison, WI.

Hatfield, D., \& Shaffer, D. W. (2006). Press play: Designing an epistemic game engine for journalism. In S. A. Barab, Hay, K. E., \& Hickey, D. T. (Ed.), ICLS 2006: 7th International Conference of the Learning Sciences (pp. 236-242). Mahwah, NJ: Lawrence Erlbaum Associates. 


\section{SCIENCE JOURNALISM FOR SCIENCE LITERACY}

Herrenkohl, L. R., and Guerra, M. R. (1998). Participant structures, scientific discourse and student engagement in fourth grade. Cognition and Instruction, 16, 431-473. doi:10.1207/s1532690xci1604_3

Hope, J. M. G. (2012). Exploring the nature of high school student engagement with science and technology as an outcome of participation in science journalism. Doctoral dissertation, University of Missouri-St. Louis. Available: https://apps.umsl.edu/webapps/weboffice/ETD/query.cfm?id=r7241

Horrigan, J. B. (2006). The Internet as a resource for news and information about science. Washington, DC: Pew Internet \& American Life Project, November 20, 2006, Available:

http://www.pewinternet.org/Reports/2006/The-Internet-as-a-Resource-for-News-and-Information-aboutScience.aspx.

Hurd, P. D. (1958). Science literacy: Its meaning for American schools. Educational Leadership, 16, 13-16. doi:10.1021/ja01549a098

Hurd, P. D. (1998). Scientific literacy: New minds for a changing world. Science Education, 82(3), 407-416. doi:10.1002/(SICI)1098-237X(199806)82:3<407::AID-SCE6>3.0.CO;2-G

Ito, M., Gutiérrez, K., Livingstone, S., Penuel, B., Rhodes, J., Salen, K., Schor, J., Sefton-Green, J., and Watkins, S. C. (2013). Connected learning: An agenda for research and design. Irvine, CA: Digital Media and Learning Research Hub.

Jarman, R., and McClune, B. (2007). Developing scientific literacy: Using news media in the classroom. New York: Open University Press/McGraw-Hill Education.

Jenkins, E.W. (1990). Scientific literacy and science education. School Science Review, 71(256), 43-51.

Kelly, G. J. (2011). Scientific literacy, discourse, and epistemic practices. In C. Linder, Östman, L., Roberts, D. A., Wickman, P.-O., Erickson, G., \& MacKinnon, A. (Ed.), Exploring the landscape of scientific literacy (pp. 6273). New York: Routledge/Taylor and Francis Group.

Kirshner, B., and Polman, J. L. (2013). Adaptation by design: A context-sensitive, dialogic approach to interventions. In Fishman, B., Penuel, W. R., Allen, A., \& Cheng, B. H. (Eds.). Design-based implementation research: Theories, methods, and exemplars. National Society for the Study of Education Yearbook, Volume 112, Issue 2 (pp. 215-236). New York: Teachers College Press.

Kohnen, A. M. (2012). Teachers as editors, editors as teachers. In C. Bazerman, C. Dean, J. Early, K. Lunsford, S. Null, P. Rogers, \& A. Stansell (Eds.), International advances in writing research: Cultures, places, measures (pp. 303-317). Fort Collins, CO: The WAC Clearinghouse.

Kohnen, A. M. (2013a). The authenticity spectrum: The case of a science journalism writing project. English Journal, 102(5), 28-34.

Kohnen, A. M. (2013b). Content-area teachers as teachers of writing. Teaching/Writing: The Journal of Writing Teacher Education, 2(1), 29-33.

Kohnen, A. M. (2013c). 'I wouldn't have said it that way': Mediating professional editorial comments in a secondary science classroom. Linguistics and Education, 24(2), 75-85. http://dx.doi.org/10.1016/j.linged.2012.12.007

Kohnen, A. M. (2013d). Informational writing in high school science: The importance of genre, apprenticeship, and publication. Journal of Adolescent and Adult Literacy, 57(3), 233-242. doi:10.1002/JAAL.220

Kolstø, S. D. (2001). Scientific literacy for citizenship: Tools for dealing with the science dimension of controversial socioscientific issues. Science education, 85(3), 291-310.

Korpan, C. A., Bisanz, G. L., Bisanz, J. \& Henderson (1997). Assessing Literacy in Science: Evaluation of Scientific News Briefs. Science Education, 81(5), 515-532. doi:10.1002/(SICI)1098237X(199709)81:5<515::AID-SCE2>3.0.CO;2-Da

Kovach, B., and Rosenstiel, T. (2007). The elements of journalism. New York: Three Rivers Press.

Krajcik, J., Blumenfeld, P., Marx, R.W., Bass, K.M., Fredricks, J., \& Soloway, E. (1998). Inquiry in project-based science classrooms: Initial attempts by middle school students. The Journal of the Learning Sciences, 7(3 \& 4), 313-350. doi:10.1080/10508406.1998.9672057

Lamb, G. R., Polman, J. L., Newman, A., and Graville Smith, C. (2014). Science news infographics: Teaching students to gather, interpret, and present information graphically. The Science Teacher, 81(3), 25-30.

Lampert, M. (1986). Knowing, doing, and teaching multiplication. Cognition and Instruction, 3(4), 305-342.

Lave, J., \& Wenger, E. (1991). Situated learning: Legitimate peripheral participation. Cambridge: Cambridge University Press.

Lave, J., and Wenger, E. (2005). Practice, person, and social world. In Daniels, H. (Ed.). An introduction to Vygotsky (pp. 145-152). New York: Routledge.

Layton, D., Jenkins, E., Macgill, S., \& Davey, A. (1993). Inarticulate science? Perspectives on the public understanding of science and some implications for science education. Leeds, England: University of Leeds. 


\section{SCIENCE JOURNALISM FOR SCIENCE LITERACY}

Lederman, N. G. (1992). Students' and teachers' conceptions of the nature of science: A review of the research. Journal of research in science teaching, 29(4), 331-359. doi:10.1002/tea.3660290404

Lehrer, R., \& Schauble, L. (2006). Cultivating model-based reasoning in science education. In R. K. Sawyer (Ed.), Cambridge handbook of the learning sciences. Cambridge, UK: Cambridge University Press.

Lemke, J. L. (1990). Talking science: Language, learning, and values. Norwood, NJ: Ablex.

Linder, C., Östman, L., Roberts, D. A., Wickman, P.-O., Erickson, G., \& MacKinnon, A. (Ed.). (2011). Exploring the landscape of scientific literacy. New York: Routledge/Taylor and Francis Group.

Linn, M. C., Clark, D., and Slotta, J. D. (2003). WISE design for knowledge integration. Science Education, 87, 517-538. doi: $10.1002 /$ sce. 10086

Manjoo, F. (2008). True enough: Learning to live in a post-fact society. Hoboken, NJ: John Wiley and Sons.

McClune, B., and Jarman, R. (2012). Encouraging and equipping students to engage critically with science in the news: What can we learn from the literature? Studies in Science Education, 48(1), 1-49. doi:10.1080/03057267.2012.655036

McGarity, T. O., and Wagner, W. E. (2008). Bending science: How special interests corrupt public health research. Cambridge, MA: Harvard University Press.

Meredith, W. (2010). What happens to your body if you stop smoking right now? (Update!). Accessed March 27, 2012. http://blisstree.com/feel/what-happens-to-your-body-if-you-stop-smoking-right-now/

Michaels, D. (2008). Doubt is their product: How industry's assault on science threatens your health. New York: Oxford University Press.

Micheals, S., Shouse, A. W., \& Schweingruber, H. A. (2008). Ready, set, science! Putting research to work in K-8 science classrooms. Washington, DC: National Academies Press.

Miller, G. A. (2003). The cognitive revolution: a historical perspective. Trends in cognitive sciences, 7(3), 141-144.

Mooney, C. \& Kirshenbaum, S. (2009). Unpopular science. The Nation, August 17, 2009. http://www.thenation.com/article/unpopular-science\#

Nasir, N. S., and Hand, V. (2008). From the court to the classroom: Opportunities for engagement, learning, and identity in basketball and classroom mathematics. The Journal of the Learning Sciences, 17(2), 143-179. doi:10.1080/10508400801986108

Nasir, N.S. \& Saxe, G. B. (2003). Ethnic and academic identities: A cultural practice perspective on emerging tensions and their management in the lives of minority students. Educational Researcher, 32(5), 14-18.

National Association of Science Writers (NASW). (n.d.). NASW code of ethics. Retrieved July 7, 2013 from http://www.nasw.org/nasw-code-ethics

National Research Council. (1996). National science education standards. Washington, DC: National Academies Press.

National Research Council. (2000). Inquiry and the national science education standards: A guide for teaching and learning. Washington, DC: National Academies Press.

National Research Council (2012a). Education for life and work: Developing transferable knowledge and skills in the 21st century. Washington, DC: National Academies Press.

National Research Council. (2012b). A Framework for K-12 Science Education: Practices, Crosscutting Concepts, and Core Ideas. Washington, DC: National Academies Press.

Nelkin, D. (1995). Selling science: How the press covers science and technology (Revised ed.). New York: Freeman.

Norris, S. P., \& Phillips, L. M. (1994). Interpreting pragmatic meaning when reading popular reports of science. Journal of research in science teaching, 31(9), 947-967.

Norris, S. P., \& Phillips, L. M. (2003). How literacy in its fundamental sense is central to scientific literacy. Science Education, 87(2), 224-240. doi:10.1002/sce.10066

OECD (2009). PISA [Programme for International Student Assessment] 2009 assessment framework: Key competencies in reading, mathematics and science. Paris, France: Organisation for Economic Co-operation and Development.

O’Neill, D. K., \& Polman, J. L. (2004). Why educate "little scientists?" Examining the potential of practice-based scientific literacy. Journal of Research in Science Teaching, 41(3), 234-266.

Pea, R. D. (1993). The collaborative visualization project. Communications of the ACM, 36(5), 60-63. doi:10.1145/155049.155063

Pellechia, M. G. (1997). Trends in science coverage: A content analysis of three US newspapers. Public Understanding of Science 6, pp. 49-68. 


\section{SCIENCE JOURNALISM FOR SCIENCE LITERACY}

Pew Research Center for the People \& the Press. (2009). Fewer Americans see solid evidence of global warming: Modest support for "cap and trade" policy. Washington, DC: Pew Research Center. Available: http://pewresearch.org/pubs/1386/cap-and-trade-global-warming-opinion

Philips, S. U. (1972). Participant structures and communicative competence: Warm Springs children in community and classroom. In A. Duranti (Ed.), Linguistic anthropology: A reader (pp. 370-394). New York: Teachers College Press.

Polman, J. L., and Hope, J. M. G. (2014). Science news stories as boundary objects affecting engagement with science. Journal of Research in Science Teaching, 51 (3), 315-341. doi: 10.1002/tea.21144

Polman, J. L., and Miller, D. (2010). Changing stories: Trajectories of identification among African American youth in a science outreach apprenticeship. American Educational Research Journal, 47(4), 879-918. doi: $10.3102 / 0002831210367513$

Polman, J. L., Newman, A., Farrar, C., and Saul, E. W. (2012). Science journalism: Students learn lifelong science literacy skills by reporting the news. The Science Teacher, 79(1), 44-47.

Polman, J. L., Saul, E. W., Newman, A., Farrar, C., Singer, N., Turley, E, Pearce, L., Hope, J., McCarty, G., and Graville, C. (2010). A cognitive apprenticeship for science literacy based on journalism. In Gomez, K., Lyons, L., \& Radinsky, J. (Eds.) Learning in the Disciplines: Proceedings of the 9th International Conference of the Learning Sciences (ICLS 2010) - Volume 2, Short Papers, Symposia, and Selected Abstracts, pp. 61-69. International Society of the Learning Sciences: Chicago IL.

Postman, N. (1992). Technopoly: The surrender of culture to technology. New York: Alfred A. Knopf.

Rahm, J., Miller, H. C., Hartley, L., and Moore, J. C. (2003). The value of an emergent notion of authenticity: Examples from two student / teacher - scientist partnership programs. Journal of Research in Science Teaching, 40(8), 737-756. doi:10.1002/tea.10109

Renninger, K.A. (2009). Interest and identity development in instruction: An inductive model. Educational Psychologist, 44(2), 105-118.

Roberts, D. A. (2007). Scientific literacy/science literacy. In S. Abell \& N. Lederman (Eds.), Handbook of Research on Science Education (pp. 729-780). Lawrence Erlbaum Associates.

Roberts, D. A. (2011). Competing visions of scientific literacy: Influence of a science curriculum policy image. In C. Linder, Östman, L., Roberts, D. A., Wickman, P.-O., Erickson, G., \& MacKinnon, A. (Ed.), Exploring the landscape of scientific literacy (pp. 11-27). New York: Routledge/Taylor and Francis Group.

Rosebery, A. S., Warren, B., \& Conant, F. R. (1992). Appropriating scientific discourse: Findings from language minority classrooms. The Journal of the Learning Sciences, 2(1), 61-94. doi:10.1207/s15327809j1s0201_2

Roth, W.-M., \& Barton, A. C. (2004). Rethinking scientific literacy. New York: Routledge.

Roth, W.-M., \& Lee, S. (2004). Science education as/for participation in the community. Science Education, $88(2)$, 263-291. doi:10.1002/sce.10113

Ruopp, R., Gal, S., Drayton, B., \& Pfister, M. (Ed.). (1993). LabNet: Toward a community of practice. Hillsdale, NJ: Lawrence Erlbaum Associates.

Russell, C. (2007). What does the future hold for science journalism? ScienceWriters, 56(4), 1.

Russell, C. (2008). Science reporting by press release. Columbia Review Journalism. November 14, 2008. http://www.cjr.org/the_observatory/science_reporting_by_press_rel.php?page=all

Rutherford, F. J., \& Ahlgren, A. (1989) Science for all Americans. Washington, D.C.: American Association for the Advancement of Science.

Saul, W., Kohnen, A., Newman, A., Pearce, L. (2012) Front page science: Engaging teens in science literacy. Arlington, VA: NSTA Press.

Schneider, S. (2009, February). Climate change and the media. Presentation at the Annual Meeting of the American Association for the Advancement of Science, Chicago, IL.

Schwab, J. J., \& Brandwein, P. F. (1962). The teaching of science as enquiry. In J. J. Schwab and P. F. Brandwein (Eds.), The teaching of science (pp. 1-103). Cambridge, MA: Harvard University Press.

Schwartz, D. L., \& Heiser, J. (2006). Spatial representations and imagery in learning. In R. K. Sawyer (Ed.), Cambridge handbook of the learning sciences. Cambridge, UK: Cambridge University Press.

Schwitzer, G. (2009). The state of health journalism in the U.S. Kaiser Family Foundation: Menlo Park, CA.

Seethaler, S. (2009). Lies, damned lies, and science: How to sort through the noise around global warming, the latest health claims, and other scientific controversies. Upper Saddle River, NJ: FT Press.

Shaffer, D. W. (2005). Epistemography and the participant structures of a professional practicum: A story behind the story of Journalism 828. Madison, WI: University of Wisconsin-Madison, Wisconsin Center for Education Research.

Shaffer, D. W. (2006). How computer games help children learn. New York: Palgrave Macmillan. 


\section{SCIENCE JOURNALISM FOR SCIENCE LITERACY}

Shaffer, D. W., and Resnick, M. (1999). "Thick" authenticity: New media and authentic learning. Journal of Interactive Learning Research, 10(2), 195-215.

Shamos, M. H. (1995). The myth of scientific literacy. New Brunswick, NJ: Rutgers University Press.

Shie, J. S. (2012). The alignment of generic discourse units in news stories. Text \& Talk, 32 (5), 661-679. doi: $10.1515 /$ text-2012-0031

Shute, N. (2006). Taking your story to the next level. In D. Blum, M. Knudson, R. M. Henig (Eds.), A field guide for science writers, $2^{\text {nd }}$ edition (pp. 34-38). New York: Oxford University Press.

Siegfried, T. (2006). Reporting from science journals. In D. Blum, M. Knudson, R. M. Henig (Eds.), A field guide for science writers, $2^{\text {nd }}$ edition (pp. 11-17). New York: Oxford University Press.

Taubes, G. (1993). Bad science: The short life and weird times of cold fusion. New York: Random House.

Trefil, J. (2008). Why science? New York/Arlington: Teachers College Press/NSTA Press.

Turner, S. (2008). School science and its controversies: or whatever happened to science literacy? Public Understanding of Science, 17, 55-72. doi:10.1177/0963662507075649

Wenger, E. (1998). Communities of practice: Learning, meaning, and identity. New York: Cambridge University Press.

Wertsch, J. V. (1991). Voices of the mind: A sociocultural approach to mediated action. Cambridge, MA: Harvard University Press.

Wertsch, J. V. (1998). Mind as action. New York: Oxford University Press.

Wineburg, S. (2001). Historical thinking and other unnatural acts: Charting the future of teaching the past. Philadelphia: Temple University Press.

Wikipedia (2012). Smoking cessation (Section "Health Benefits"). Accessed March 27, 2012. http://en.wikipedia.org/wiki/Quit smoking\#Health benefits

Wortham, S. (2006). Learning identity: The joint emergence of social identification and academic learning. New York: Cambridge University Press.

Yam, P. M. (2006). Finding story ideas and sources. In D. Blum, M. Knudson, R. M. Henig (Eds.), A field guide for science writers, $2^{\text {nd }}$ edition (pp. 5-10). New York: Oxford University Press.

Zeidler, D. L., and Sadler, T. D. (2011). An inclusive view of scientific literacy: Core issues and future directions. In C. Linder, Östman, L., Roberts, D. A., Wickman, P.-O., Erickson, G., \& MacKinnon, A. (Ed.), Exploring the landscape of scientific literacy (pp. 176-192). New York: Routledge/Taylor and Francis Group. 